\title{
Length-length and length-weight relationships of critically endangered striped cat fish Rita rita (Hamilton) from the Padda River near Rajshahi of Northwestern Bangladesh
}

\author{
Syeda Mushahida-Al-Noor \\ Department of Fisheries, Faculty of Agriculture, University of Rajshahi, Rajshahi 6205, Bangladesh
}

\begin{abstract}
The present study describes the length-length (LLR) relationships for critically endangered catfish Rita rita (Hamilton, 1822) from the Ganges River, northwestern Bangladesh. A total of 379 specimens used for this study were caught by traditional fishing gear from January to December 2011. Total length (TL), standard length (SL), fork length $(F L)$, snout length $(S n L)$, head length (HL), pre-dorsal length (PrDL), post-dorsal length (PoDL), Anal length (AnaL) and Anus length (AnsL) were measured and relationships were calculated by linear regressions. Parameters $a$ and $b$ of the weight-length relationship were estimated by least squares regression analysis. Most LLRs relationships were highly significant with ' $r$ ', values greater than 0.845 . Exceptions were found incase of $T L-H L$ relationship of female $\left(r^{2}=0.756\right) ; T L-S n L$ relationships of male $\left(r^{2}=0.701\right)$ and combined sexes $\left(r^{2}=0.656\right), T L-P r D L$ relationship for combined sexes $\left(r^{2}=0.692\right)$ and $T L$ AnsL relationship for female $\left(r^{2}=0.722\right)$ and combined sexes $\left(r^{2}=0.695\right)$. TL-BW relationships were highly significant with ' $r$ ' values greater than 0.845 for male, female and combined sexes. The calculated allometric coefficient ranged from 0.914 to $1.159(b<3)$, so the fish showed negative allometric pattern of growth.

To the best knowledge of the authors, this study presented the first reference on LLRs for these species from Bangladeshi waters.
\end{abstract}

Keyword: Ritha, Padma river, riverine catfish, LLRs, LWRs and morphometric characteristics

\section{Introduction}

Inland open water fishery resources play a significant role in the economy, culture, tradition and food habits of the people of Bangladesh (Kibria and Ahmed, 2005). There are 260 recorded indigenous freshwater bony fish species within 145 genera and 55 families (Craig et al., 2004). Rita rita (Hamilton, 1822) is a critically endangered catfish of Bangladesh and is locally known as Rithe in Bangladesh. This fresh water species inhabit muddy to clean water and my found in streams, rivers, canals and ponds; occurs mainly in shallow waters (Mirza, 2002).Young fishes are greenish brown above and silvery brown on back of body. Rita. rita is a bottom and column feeder, feeds on aquatic algae and higher plants as well as insects, crustaceans and rotifers. It survives well in all fresh water below an altitude of approximately $549 \mathrm{~m}$. It is extremely slimy when captured (Rahman, 2005).

Length-length relationships (LLRs) are also important for comparative growth studies (Moutopoulos and Stergiou, 2002). LLR are still scare for most tropical and sub-tropical fish species (Martin-Smith, 1996; Harrison,2001; Ecoutin et al., 2005). Length-length relationships (LLRs) are also important in fisheries management for comparative growth studies (Moutopoulos and Stergiou, 2002). Although LLRs are readily available for most European and North American freshwater and marine fishes (e.g. Bagenal and Tesch, 1978; Petrakis and Stergiou, 1995; Koutrakis and Tsikliras, 2003; Sinovcic et al., 2004; Leunda et al., 2006; Miranda et al., 2006), adequate local information is still scarce for most tropical and subtropical fish species (Harrison, 2001; Ecoutin et al., 2005).Length-weight relationships (LWRs) are useful in fishery management for both applied and basic use (Pitcher and Hart, 1982) to: (i) estimate weight from length observations; (ii) calculate production and biomass of a fish population; and/or (iii) provide information on stocks or organism condition at the corporal level. The morphometric relationships between length and weight can be used to assess the wellbeing of individuals and to determine possible differences between separate unit stocks of the same species (King, 2007). Length-weight relationships (LWRs) are needed to estimate weight from length because direct weight measurements can be time-consuming in the field (Koutrakis and Tsikliras, 2003; Sinovcic et al., 2004); these parameters are important in fish biology and can provide information on the stock condition (Bagenal and Tesch, 1978).

At present no published information is available on length-length and length-weight relationships of this commercially important catfish from Bangladesh. Only Sandhu and Lone (2003) published information on food and feeding habits of Rita rita. Few isolated studies like Devi et al., (1990) reported age and growth; Devi et al., (1992) studied food and feeding habit of Rita rita from India and Narejo et al., (2009) studied the length-weight relationships (LWRs) of Rita rita from Sindh,Pakistan. Subsequently, the aim of the present paper was to carry 
out the complete description of the LWRs and LLRs of this species from the Ganges River, north-western Bangladesh.

\section{Materials and methods}

The Padda River is a branch of the Ganges River, located near Rajshahi, north-western region of Bangladesh $\left(24 \circ 22^{\prime} \mathrm{N} ; 88^{\circ} 25^{\prime} \mathrm{E}\right)$. It is believed to be an important spawning and feeding ground of riverine fish species in northwestern Bangladesh. Striped catfish specimens were collected monthly from the different sampling sites in the Padda River during daytime (10:00-17:00 hours) from January to December, 2010 by means of traditional fishing gear jhaki jal (cast net) and dughair (conical trap) (Kibria and Ahmed, 2005). Specimens were preserved in $10 \%$ buffered formalin, packed in wooden boxes and transported to the laboratory. All specimens (379) were sexed by gonad observation under a binocular microscope. Total length (TL), standard length (SL), fork length (FL), snout length (SnL), head length (HL), pre-dorsal length (PrDL), postdorsal length (PoDL), Anal length (AnaL) and Anus length (AnsL) were measured with a slide caliper to the nearest $0.01 \mathrm{~cm}$, whilst body weight (BW) was determined with a digital balance to the nearest $0.01 \mathrm{~g}$.. The statistical significance level of $\mathrm{r}^{2}$ was estimated and the parameters a and $\mathrm{b}$ were estimated by linear regressions. Moreover (i) TL vs SL; (ii) TL vs. FL;(iii)TL vs. HL;(iv)TL vs. SnL; (v)TL vs. PrDL; (vi)TL vs. PoDL; (vii)TL vs. AnaL; (viii)TL vs. AnsL relationships were calculated by linear regressions. To test for possible significant differences in both slope and intercept, we followed the analysis of covariance. Parameters a and $b$ of the weight-length relationship were estimated by least squares regression analysis of the logarithm transformed LWR expression: $\ln (\mathrm{W})=\ln (\mathrm{a})+\mathrm{b} \ln (\mathrm{L})$ (Beverton and Holt,1957), where the $\mathrm{W}$ is the body weight $(\mathrm{g})$, L the total length $(\mathrm{cm})$, "a" the intercept of the regression and b is the regression coefficient (slope). The determination coefficient $\left(\mathrm{r}^{2}\right)$ was used as an indicator of the quality of the linear regressions (Scherrer, 1984). All the statistical analyses were considered at significance level of $5 \%(\mathrm{P}<0.05)$.

\section{Results}

From the total of specimens of $R$. rita collected during the study period, 173(45.65\%) were males and 206(54.3\%) were females. Total length and different body length relationships have been used widely in the fishes for assessing their growth and other characteristics. For analyzing length-length relationship of Rita rita, the sample presented were large and covered reasonable size ranged from $19.1 \mathrm{~cm}$ to $31.9 \mathrm{~cm}$. Most LLRs relationships were highly significant with ' $\mathrm{r}$ ', values greater than 0.845 . Exceptions were found incase of TLHL relationship of female $\left(\mathrm{r}^{2}=0.756\right)$; TL-SnL relationships of male $\left(\mathrm{r}^{2}=0.701\right)$ and combined $\operatorname{sexes}\left(\mathrm{r}^{2}=0.656\right)$, TL-PrDL relationship for combined $\operatorname{sexes}\left(\mathrm{r}^{2}=0.692\right)$ and TL-AnsL relationship for female $\left(\mathrm{r}^{2}=0.722\right)$ and combined $\operatorname{sexes}\left(r^{2}=0.695\right)$. From the length-length relationship equations, it is observed that all length increases with increase of TL which is the expected linear relationship. The body weights (BW) of the fishes were obtained from $66.85 \mathrm{~g}$ to $658.61 \mathrm{~g}$ (male) and from $78.3 \mathrm{~g}$ to $820.52 \mathrm{~g}$ (female). TL-BW relationships were highly significant with ' $r$ ' , values greater than 0.845 for male, female and combined sexes. The calculated allometric coefficient ranged from 0.914 to $1.159(b<3)$, so the fish showed negative allometric pattern of growth.

Table-1 Relationship between total length, fork length, slandered length, head length and anal length of males, females and combined sexes. The values of intercepts (a), regression co-efficient (b) and determination coefficient $\left(\mathrm{r}^{2}\right)$ are shown in the following table.

\begin{tabular}{|c|c|c|c|c|c|c|c|}
\hline \multicolumn{2}{|c|}{$\begin{array}{l}\text { Relation } \\
\text { between }\end{array}$} & \multirow[t]{2}{*}{ Sex } & \multirow[t]{2}{*}{$\begin{array}{l}\text { Mean } \pm \text { SD } \\
\text { ' } x \text { ' }\end{array}$} & \multirow[t]{2}{*}{$\begin{array}{l}\text { Mean } \pm \text { SD } \\
\text { 'Y' }\end{array}$} & \multirow[t]{2}{*}{$\begin{array}{l}\text { Value } \\
\text { of 'a' }\end{array}$} & \multirow[t]{2}{*}{$\begin{array}{l}\text { Value } \\
\text { of 'b' }\end{array}$} & \multirow[t]{2}{*}{$\begin{array}{l}\text { Value of } \\
\text { ' } r^{2} \text { ' }\end{array}$} \\
\hline $\mathbf{X}$ & $\mathbf{Y}$ & & & & & & \\
\hline \multirow[t]{3}{*}{ TL } & \multirow[t]{3}{*}{ FL } & Male & $20.45 \pm 4.48$ & $19.04 \pm 3.80$ & 0.665 & 0.835 & 0.972 \\
\hline & & Female & $25.57 \pm 4.34$ & $23.72 \pm 3.94$ & 0.526 & 0.903 & 0.992 \\
\hline & & Combine & $22.43 \pm 5.08$ & $21.66 \pm 4.87$ & 0.489 & 0.935 & 0.952 \\
\hline \multirow[t]{3}{*}{ TL } & \multirow[t]{3}{*}{ SL } & Male & $20.45 \pm 4.48$ & $18.68 \pm 0.86$ & 0.987 & 0.731 & 0.946 \\
\hline & & Female & $25.57 \pm 4.34$ & $21.75 \pm 3.98$ & 0.946 & 0.796 & 0.956 \\
\hline & & Combined & $22.43 \pm 5.08$ & $20.17 \pm 4.59$ & 1.104 & 0.776 & 0.937 \\
\hline \multirow[t]{3}{*}{ TL } & \multirow[t]{3}{*}{ HL } & Male & $20.45 \pm 4.48$ & $5.93 \pm 3.36$ & 1.028 & 0.178 & 0.864 \\
\hline & & Female & $25.57 \pm 4.34$ & $5.79 \pm 0.97$ & 0.807 & 0.195 & 0.756 \\
\hline & & Combined & $22.43 \pm 5.08$ & $5.11 \pm 1.05$ & 0.791 & 0.192 & 0.859 \\
\hline \multirow[t]{3}{*}{ TL } & \multirow[t]{3}{*}{ SnL } & Male & $20.45 \pm 4.48$ & $2.16 \pm 0.88$ & -1.218 & 0.165 & 0.701 \\
\hline & & Female & $25.57 \pm 4.34$ & $2.08 \pm 0.53$ & -0.834 & 0.114 & 0.885 \\
\hline & & Combined & $22.43 \pm 5.08$ & $2.13 \pm 0.76$ & -1.132 & 0.117 & 0.656 \\
\hline \multirow[t]{2}{*}{ TL } & \multirow[t]{2}{*}{ PrDL } & Male & $20.45 \pm 4.48$ & $6.58 \pm 1.62$ & -0.691 & 0.355 & 0.966 \\
\hline & & Female & $25.57 \pm 4.34$ & $6.80 \pm 1.90$ & -0.664 & 0.342 & 0.846 \\
\hline
\end{tabular}


Length-length and length-weight relationships of critically endangered striped cat fish Rita rita

\begin{tabular}{|l|l|l|l|l|l|l|l|}
\hline & & Combined & $22.43 \pm 5.08$ & $6.59 \pm 1.73$ & -0.668 & 0.383 & 0.692 \\
\hline \multirow{2}{*}{ TL } & \multirow{2}{*}{ PoDL } & Male & $20.45 \pm 4.48$ & $6.67 \pm 1.50$ & -0.200 & 0.327 & 0.954 \\
\cline { 3 - 8 } & & Female & $25.57 \pm 4.34$ & $9.27 \pm 1.18$ & -0.152 & 0.320 & 0.851 \\
\cline { 3 - 8 } & Combined & $22.43 \pm 5.08$ & $7.67 \pm 1.88$ & -0.160 & 0.349 & 0.893 \\
\hline \multirow{2}{*}{ TL } & \multirow{2}{*}{ ansL } & Male & $20.45 \pm 4.48$ & $11.59 \pm 3.01$ & -1.645 & 0.568 & 0.931 \\
\cline { 3 - 8 } & & Female & $25.57 \pm 4.34$ & $14.89 \pm 2.42$ & -1.651 & 0.528 & 0.722 \\
\cline { 3 - 8 } & & Combined & $22.43 \pm 5.08$ & $12.87 \pm 3.22$ & -1.615 & 0.604 & 0.695 \\
\hline \multirow{2}{*}{ TL } & \multirow{2}{*}{ AnaL } & Male & $20.45 \pm 4.48$ & $11.59 \pm 3.01$ & -1.858 & 0.587 & 0.966 \\
\cline { 3 - 8 } & & Female & $25.57 \pm 4.34$ & $15.89 \pm 2.42$ & -1.841 & 0.556 & 0.974 \\
\cline { 3 - 8 } & & Combined & $22.43 \pm 5.08$ & $12.87 \pm 3.22$ & -1.249 & 0.614 & 0.970 \\
\hline
\end{tabular}

Table-2 The least squares regression analysis of the logarithm transformed in length-weight relations are obtained in case of male, female and combined sexes.

\begin{tabular}{|c|c|c|c|c|c|c|c|}
\hline \multicolumn{2}{|c|}{$\begin{array}{l}\text { Relationship } \\
\text { between }\end{array}$} & Sex & $\begin{array}{l}\text { Mean } \pm \text { SD }(\mathrm{cm}) \\
\text { 'TL' }\end{array}$ & $\begin{array}{l}\text { Mean } \pm \text { SD }(g) \\
\text { 'BW' }\end{array}$ & $\begin{array}{l}\text { Value } \\
\text { of 'a' }\end{array}$ & $\begin{array}{l}\text { Value } \\
\text { of 'b' }\end{array}$ & $\begin{array}{l}\text { Value } \\
\text { of ' } r^{2} \text {, }\end{array}$ \\
\hline \multirow[t]{3}{*}{ TL } & \multirow[t]{3}{*}{ BW } & Male & $20.45 \pm 4.48$ & $697.20 \pm 5.76$ & 2.909 & 1.159 & 0.971 \\
\hline & & Female & $25.57 \pm 4.34$ & $588.40 \pm 7.03$ & 2.9 & 1.068 & 0.949 \\
\hline & & Combined & $22.43 \pm 5.08$ & $365.47 \pm 4.87$ & 2.946 & 0.914 & 0.939 \\
\hline
\end{tabular}

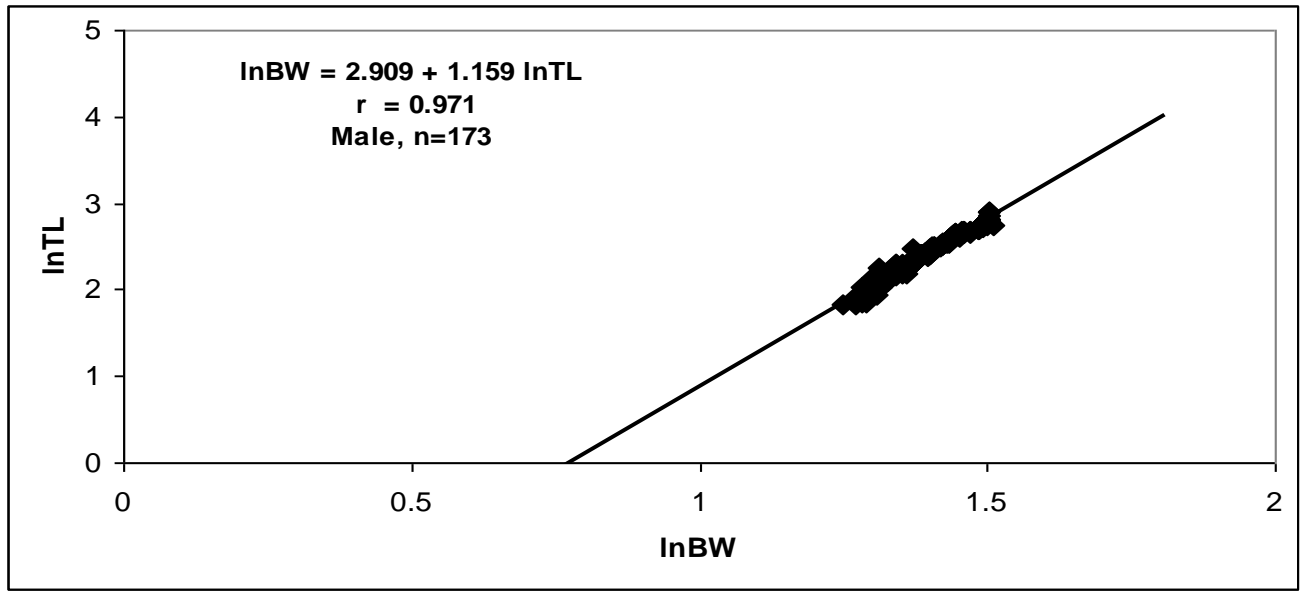

Figure 1. Length-weight relationships ( $\ln B W=\ln a+b \cdot \operatorname{lnTL}$ ) of Rita rita for male from the Padda River, northwestern Bangladesh, January to December 2011.

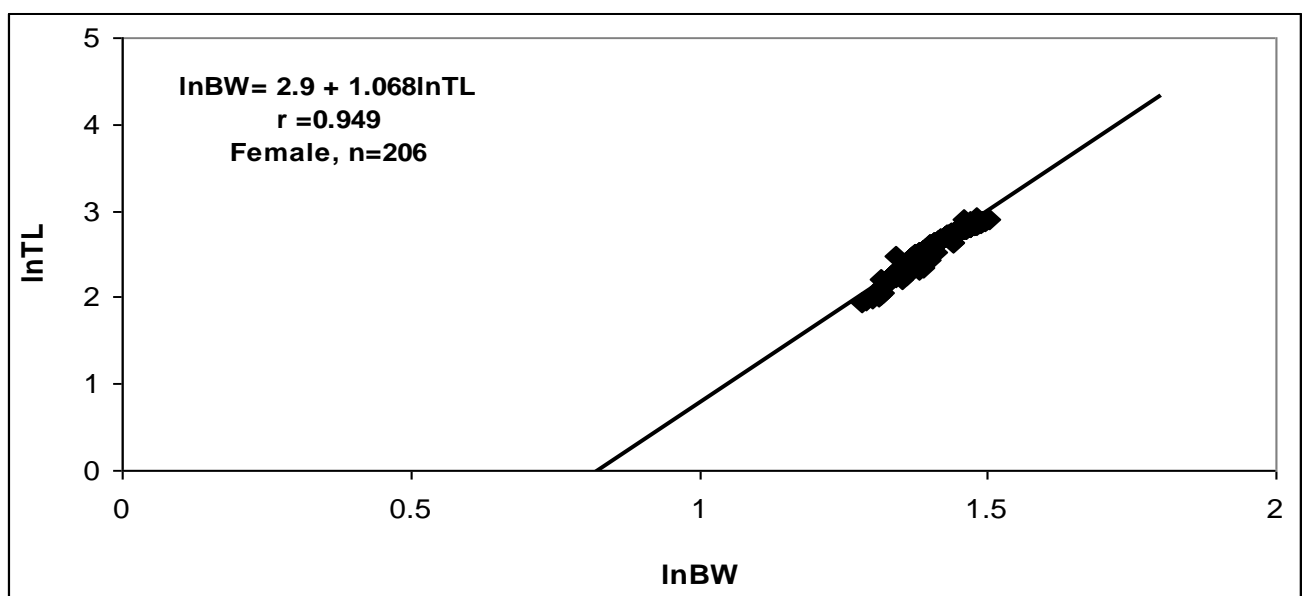

Figure 2. Length-weight relationships $(\ln B W=\ln a+b \cdot \ln T L)$ of Rita rita for female from the Padda River, northwestern Bangladesh, January to December 2011. 


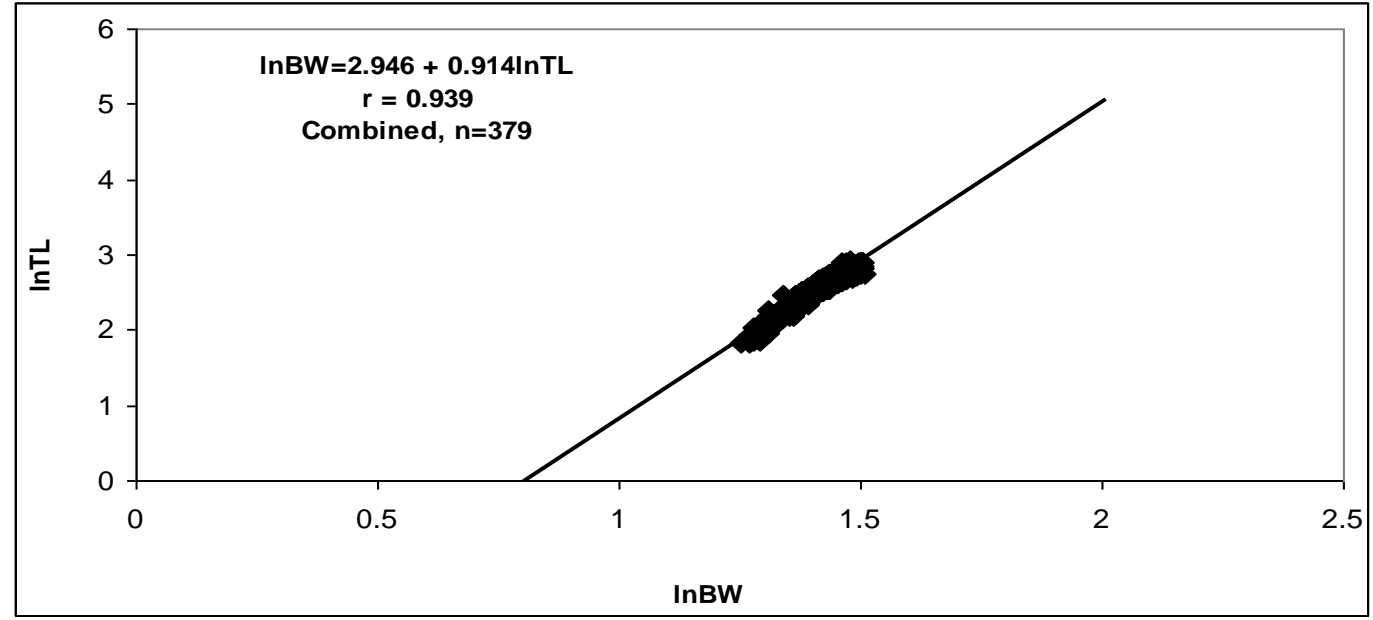

Figure 3. Length-weight relationships ( $\operatorname{lnBW}=\operatorname{lna}+\mathrm{b} \cdot \operatorname{lnTL})$ of Rita rita for combined sexes from the Padda River, northwestern Bangladesh, January to December 2011.

\section{Discussion}

Cube law is not confirmed for all fishes because growth causes for the change of their shape (Ali 1999). Wootton (1990) also described that a value less then 3.0 indicated that fish becomes lighter (negative allometric) and greater then 3.0 as heavier (positive allometric) for a particular length as it increase in size.

In the present study it was observed that there existed positive linear relationship in all the cases of the relationships between total length with different body length of Rita rita. The correlation of LLRs in the present study is similar to the findings of Hossain et al. (2009) for Mystus vittatus, Ailia coila, Clupisoma atherinoides and Eutropiichthyes vacha; Khan et al. (2012) for Ompok pabda in the Ganges.

The regional difference in TL or SL probably depends on ecological condition in area of investigation. According to Devi et al. (1991) SL=-0.054+0.812TL and $\mathrm{FL}=-1.3+0.837 \mathrm{TL}$ of Rita rita in Yamuna river of North-India. Even Najero et al. (2009) found positive allometric growth for female and combined sexes and negative allometric growth for female Rita rita(size:13.9-41.7cm and weight range:32.7-779.6g) from Sindh,Pakistan. The Total length and body weight relationship showed negative allometric pattern of growth which was different from the finding of Khan et al. (2012) for Ompok pabda (positive allometric), Wallago attu (positive allometric) and Sperata seenghala(positive allometric); Hossain (2010) for Ailia coila (Isometric); Hossain et al.(2009) for Mystus vittatus(Positive allometric)in the Ganges. The finding of the present study is similar to Clarias batrachus and Sperata aor (Khan et al.,2012); Eutropiichthys vacha and Neotropius atherinoides (Hossain,2010); Clupisoma atherinoides(Hossain et al.,2009), Heteropneustes fossilis in the Ganges and Mystus cavasius(Venkateshwarlu et.al. ,2007) from Bhadra reservoir, Karnataka.

\section{Conclusion}

This study provides an important baseline study on length-length, length-weight and condition factor of critically endangered catfish $R$. rita from Bangladesh. The results of the study would be an effective tool for fishery biologists, managers and conservationists to initiate early management strategies and regulations for the sustainable conservation of the remaining stocks of these endangered species in the Brahmaputra River ecosystem. Moreover, information on length-length, length and condition factors for this species is clearing lacking from literature and data bases including FishBase. Therefore, the results of this study provide invaluable information for the online FishBase database, as well as providing an important baseline for future studies within the Padda River and surrounding ecosystems such as the Ganges.

\section{Acknowledgement}

I am grateful to Dr. Abdus Samad, Assistant Professor, Department of Fisheries, University of Rajshahi, for his supervision and support during the study.

\section{References}

[1] Kibria, G. and Ahmed, K. K. U., 2005. Diversity of selective and nonselective fishing gear and their impact on inland fisheries in Bangladesh. NAGA, 28,43-48.

[2] Craig, J. M.; Halls, A. S.; Barr, J. J. F.; Bean, C. W., 2004. The Bangladesh floodplain fisheries. Fish. Res., 66, $271-286$.

[3] Hamiton, F. 1822. An account of the fishes found in the river Ganges and its branches. Archibald constable and company. Edinburg. Vill.405 pp. 
[4] Mirza, M.R. 2002.Checklist of freshwater fishes of Pakistan. Department of Zoology, Government College University, Lahore, Pakistan.

[5] Rahman, A.K.A. 2005. Freshwater fishes of Bangladesh. Zoll. Soc. of Bangladesh, pp.304-52.

[6] Moutopoulos, D. K.; Stergiou, K. I., 2002. Length-weight and lengthlength relationships of fish species from Aegean Sea (Greece). J. Appl. Ichthyol,. 18, 200-203.

[7] Martin-Smith, K.M. 1996. Length/weight relationships of fishes in a diverse tropical fresh-water community, Sabah, Malaysia. Journal of Fish Biology, 49, 731-734.

[8] Ecoutin, J. M.; Albaret, J. J.; Trape, S., 2005. Length-weight relationships for fish populations of a relatively undistributed tropical estuary: the Gambia. Fish. Res. 72, 347-351.

[9] Bagenal, T. B. and Tesch, F. W., 1978. Age and growth. In: Methods for assessment of fish production in fresh waters, 3rd edn. T. Begenal (Ed.). IBP Handbook No. 3, Blackwell Science Publications, Oxford, pp. 101-136.

[10] Petrakis, G.; Stergiou, K. I., 1995. Weight-length relationships for 33 fish species in Greek waters. Fish. Res. 21, 465-469.

[11] Koutrakis, E. T.; Tsikliras, A. C., 2003. Length-weight relationships of fishes from three northern Aegean estuarin systems (Greece). J. Appl. Ichthyol., 19, 258-260.

[12] Sinovcic, G.; Franicevic, M.; Zorica, B.; Cikes-Kec, V., 2004. Lengthweight and length-length relationships for 10 pelagic fish species from the Adriatic Sea (Croatia). J. Appl. Ichthyol,. 20, 156-158.

[13] Leunda, P. M.; Oscoz, J.; Miranda, R., 2006. Length-weight relationshipsof fishes from tributaries of the Ebro River,Spain. J. Appl.Ichthyol., 22, 299-300.

[14] Miranda, R.; Oscoz, J.; Leunda, P. M.; Escala, M. C., 2006. Weightlength of cyprinid fishes of the Iberian Peninsula. J. Appl. Ichthyol,. 22, 297-298.

[15] Harrison, T.D. 2001. Length-weight relationships of fishes from South African estuaries. Journal of Applied Ichthyology, 17, 46-48.

[16] Pitcher, T. J.; Hart, P. J., 1982. Fisheries Ecology. Chapman and Hall,London.

[17] King, M. 2007. Fisheries biology, assessment and management. Second Edition. Blackwell Scientific Publications, Oxford. pp.1381 .

[18] Muchlisin, Z.A., Musman, M. \& Azizah, M.N.S. 2010. Length-weight relationships and condition factors of two threatened fishes, Rasbora tawarensis and Poropuntius tawarensis, endemic to Lake Laut Tawar, Aceh Province, Indonesia. Journal of Applied Ichthyology 26(6), 949-953.

[19] Sarkar, U.K., Deepak, P.K. \& Negi, R.S. 2009. Length-weight relationship of clown knifefish Chitala chitala (Hamilton 1822) from the River Ganga basin, India. Journal of Applied Ichthyology, 25(2), 232-233.

[20] Richter, T.J. 2007. Development and evaluation of standard weight equations for bridge-lip suckers and large-scale suckers. North American Journal of Fisheries Management, 27(3), 936-939.

[21] Sandhu, A. A. and K. P. Lone. (2003) Food and feeding habits of some catfishes of Pakistan, Pakistan J. Zool.,35 (4), $353-356$.

[22] Devi, N. T., M. S. Siddique and Anwar. 1990. Age and growth of catfish Rita rita (Ham) fromthe river Yamuna in North. J Indian. Fish.Assoc,.(20), 37-41.

[23] Devi, N. T., M. S. Siddique and Anwar. 1992.On the food of catfish, Rita rita (Ham) from theriver Yamuna in North. J. Inland. Fish. Soc.India., (20), 34-39.

[24] Narejo, N. T., M.Y. Laghari, H. Mahesar, P.K. Lashari, and M. Abid. (2002). Length-weight relationship and condition of Indigenous Catfish, Rita rita (Hamilton) from cemented ponds, University of Sindh, Jamshoro. Sindh Univ. Res. Jour. (Sci. Ser.), 41 (2), 47-52.

[25] Beverton,R.J.H and S.J.Holt,1957.On the dynamics of exploited fish populations. Fish.Invest.,London.ser II. 19,533.

[26] Ali, S.S. (1999) Fresh Water Fishery Biology.Naseem Book Depot. Hyderabad. 330Pp.

[27] Wootton, R. J. (1990) Ecology of teleost fishes.Chapman and Hall, London. 405Pp.

[28] M. Y. Hossain, S. Jasmine, A. H. M. Ibrahim, Z. F. Ahmed, M. M. Rahman and J. Ohtomi.2009.Length-weight and length-length relationships of 10 small fish species from theGanges, Bangladesh. J. Appl. Ichthyol., 25, 117-119.

[29] Hossain, M.Y., Ahmed, Z. F., Leunda, P. M.,Jasmine, S., Oscoz, J. Miranda, R. and Ohtomi, J.2006. Condition, length-weightand length-length relationship of the Asianstriped catfish Mystus vittatus(Bloch, 1794)(Siluriformes: Bagridae) in the MathbhangaRiver, southwestern Bangladesh. J.Appl. Ichthyol., 22, 304-307.

[30] Hossain,M.Y.2010. Length-Weight, Length-Length Relationships and Condition Factors of Three Schibid Catfishes from the Padma River, Northwestern Bangladesh Asian Fisheries Science, 23,329-339.

[31] Venkateshwarlu, M., Srigowri, J., Somashekar, D. S. andAshashree, H. M. (2007). Length-Weight relationship and condition factor offreshwater cat fish Mystus cavasius (Hamilton-Buchanan) from Bhadra Reservoir, Karnataka.Environment \& Ecology, 25(1), 4953 . 